\title{
Chemoattraction and Chemorepulsion of Olfactory Bulb Axons by Different Secreted Semaphorins
}

\author{
Fernando de Castro, ${ }^{1}$ Lingjia Hu, ${ }^{2}$ Harry Drabkin, ${ }^{2}$ Constantino Sotelo, ${ }^{1}$ and Alain Chédotal ${ }^{1}$ \\ 1/nstitut National de la Santé et de la Recherche Médicale U106, Hôpital de la Salpêtrière, 75013 Paris, France, and \\ ¿University of Colorado Health Sciences Center, Denver, Colorado 80262
}

During development, growth cones can be guided at a distance by diffusible factors, which are attractants and/or repellents. The semaphorins are the largest family of repulsive axon guidance molecules. Secreted semaphorins bind neuropilin receptors and repel sensory, sympathetic, motor, and forebrain axons. We found that in rat embryos, the olfactory epithelium releases a diffusible factor that repels olfactory bulb axons. In addition, Sema A and Sema IV, but not Sema III, Sema E, or Sema $\mathrm{H}$, are able to orient in vitro the growth of olfactory bulb axons; Sema IV has a strong repulsive action, whereas Sema A appears to attract those axons. The expression patterns of sema $A$ and sema IV in the developing olfactory system confirm that they may play a cooperative role in the formation of the lateral olfactory tract. This also represents a further evidence for a chemoattractive function of secreted semaphorins.

Key words: semaphorin; olfactory system; chemorepulsion; chemoattraction; development; neuropilin
The organization of axonal projections in the rodent olfactory system has been extensively characterized. Axons from olfactory receptor neurons in the olfactory epithelium project ipsilaterally to glomeruli in the main olfactory bulb, where they synapse on the dendrites of the mitral and tufted cells. These neurons project ipsilaterally to the anterior olfactory nucleus and to higher olfactory centers, including the piriform and entorhinal cortex, and some amygdaloid nuclei, collectively referred to as the primary olfactory cortex (Shipley and Ennis, 1996). The axons of the mitral and tufted cells are located immediately under the pial surface (Derer et al., 1977; Schwob and Price, 1984; Marchand and Bélanger, 1991) and form the lateral olfactory tract (LOT).

The molecular mechanisms governing the establishment of axonal projections from the olfactory receptor neurons to the olfactory bulb have started to be unraveled (Wang et al., 1998). In contrast, the development of bulbof ugal projections is still poorly understood, although putative guidepost cells for LOT axons have been described (Sato et al., 1998). In the rat embryo, isolated fibers start to leave the olfactory bulb by embryonic day 14 (E14), and by E15 a LOT has clearly formed (Marchand and Bélanger, 1991; Pini, 1993; López-Mascaraque et al., 1996). At this stage of development, the great majority of postmitotic neurons in the olfactory bulb are mitral cells (Bayer, 1983). Therefore, the early LOT is almost solely composed of mitral cell axons. Organotypic co-cultures of olfactory bulb and telencephalic vesicles or membranes has shown that the telencephalon contains precisely localized, short-range positional cues that guide LOT axons (Sugisaki et al., 1995; Hirata and Fujisawa, 1997). The results of other in

Received Nov. 23, 1998; revised March 8, 1999; accepted March 11, 1999.

A.C. and C.S. are supported by Institut National de la Santé et de la Recherche Médicale and Grant BIO4-CT960-774 from the European Community (EC). F.d.C. is supported by EC Fellowship ERB-4001-GT-970077. H.D. is supported by Grants CA68383 and CA58187 from the National Institutes of Health. We thank Dr. D. J. Flanagan for the APtag4 vector and Drs. C. Christensen and A. W. Püschel for providing us with mouse sema $H$ and mouse sema $A$, respectively.

Correspondence should be addressed to Dr. Alain Chédotal, Institut National de la Santé et de la Recherche Médicale U106, Hôpital de la Salpêtrière, 47 Boulevard de l'Hôpital, 75013 Paris, France.

Copyright (C) 1999 Society for Neuroscience $\quad 0270-6474 / 99 / 194428-09 \$ 05.00 / 0$ vitro assays (Pini, 1993; Hu and Rutishauser, 1996) suggest that developing rat LOT axons can also be guided from a distance by some unidentified diff usible chemorepulsive factors produced by the septum or the neocortex.

Chemotropic factors that can attract and/or repel axons have been described in a variety of systems (Tessier-Lavigne and Goodman, 1996). To date, there are two characterized chemoattractants, netrin-1 (Kennedy et al., 1994) and the hepatocyte growth factor/scatter factor (Ebens et al., 1996). Potential chemorepellents have been identified in two gene families, the netrins and the semaphorins (Tessier-Lavigne and Goodman, 1996; Mark et al., 1997). Five secreted semaphorins are known in rodents, and they have been shown to bind receptors of the neuropilin family (Chen et al., 1997; Feiner et al., 1997; He and Tessier-Lavigne, 1997; Kolodkin et al., 1997; Takahashi et al., 1998).

Several pieces of evidence suggest that secreted semaphorins could play a role in the development of bulbofugal projections. Neuropilin-1 is highly expressed on the axons of embryonic mitral cells, and neuropilin-2 mRNA is present in all components of the olfactory circuitry (Kawakami et al., 1995; Chen et al., 1997). Moreover sema III/collapsin-1 mRNAs are found in the olfactory bulb and in the LOT pathway (Giger et al., 1996; Shepherd et al., 1996; Kobayashi et al., 1997). This has led us to investigate whether secreted semaphorins can influence the growth of LOT axons.

\section{MATERIALS AND METHODS}

Animals. Wistar rats (IFFA Credo, Lyon, France) were used for the culture experiments and for in situ hybridization studies. The day on which a vaginal plug was detected was considered E0, and the day of birth was considered postnatal day 0 . Pregnant rats were anesthetized with chloral hydrate $(350 \mathrm{mg} / \mathrm{kg}$, i.p.).

Cloning of mouse semaphorin IV sequences. Mouse semaphorin IV sequences were amplified by RT-PCR on a random-primed template from mouse A9 cells using the following primers: 59H8, 5'-TTC AAC TTC CTG CTC AAC; and 39G5, 5'-GAA GAC CAT GCG AAT ATC, which were obtained from the human $H$-sema $I V$ sequence (Roche et al., 1996). PCR conditions included 35 cycles with an annealing temperature of $55^{\circ} \mathrm{C}$ with $T a q$ DNA polymerase and buffer (Promega, Madison, WI). 

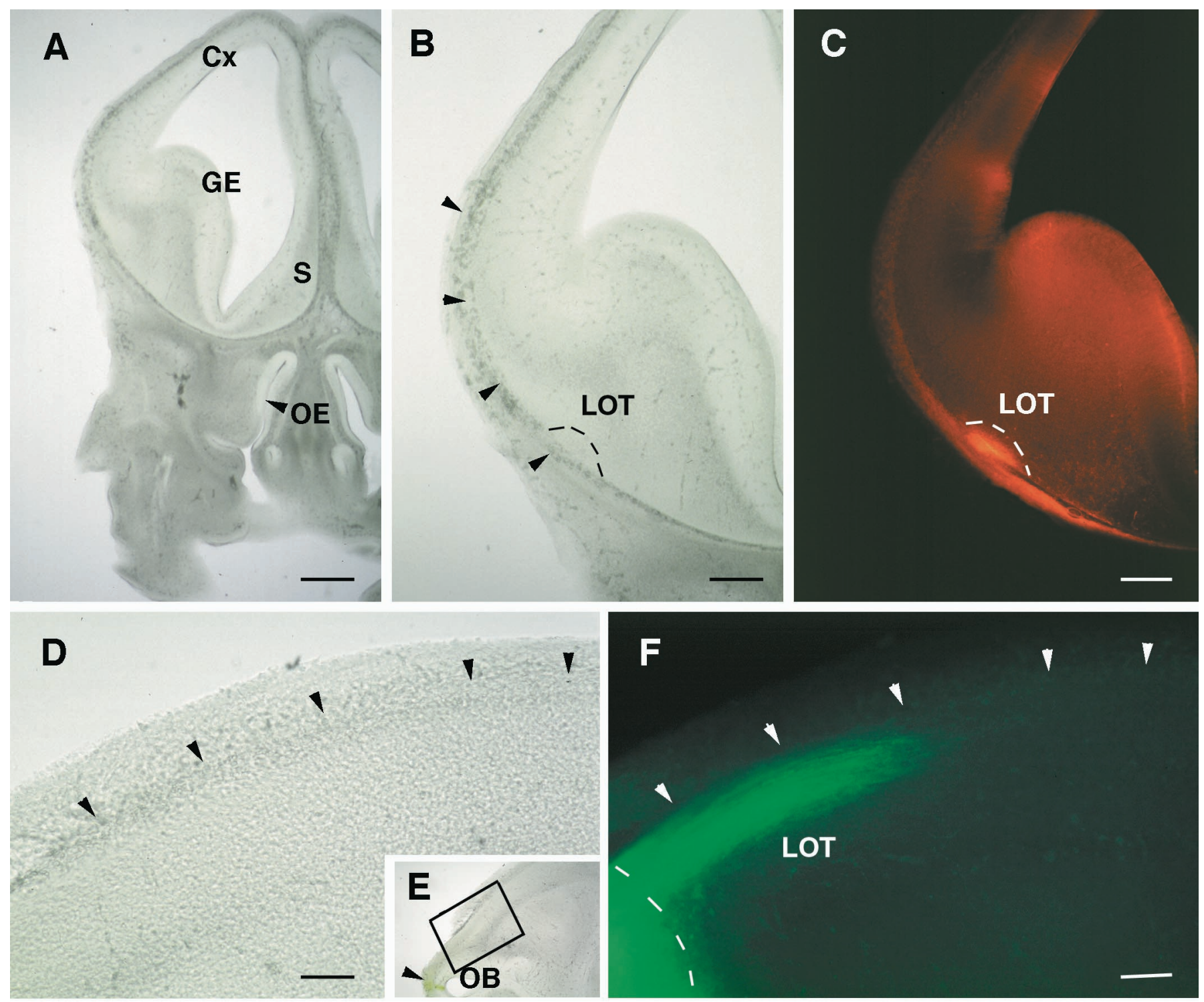

Figure 1. Illustration of the localization of the LOT in rat E15 embryos. Embryos have been injected in the OB with DiI or 4-(4dihexadecylaminostyryl)- $N$-methylpyridinium iodide (DiA) crystals. $A-C$, Coronal vibratome sections at the level of the septum $(S)$, viewed under bright-field $(A, B)$ or rhodamine filter. The LOT (outlined in $B, C)$ grows immediately under the pial surface, in the vicinity of the mesenchyme precursor of the frontal bone $(B$, arrowheads). $D-F$, Horizontal sections corresponding to the area framed in $E$. They show, at E15, the rostrocaudal extent of the LOT (labeled axon fascicle in $F)$ and the location of the frontal bone $(D, F$, arrowheads). The dashed line delimits the caudal extent of the olfactory bulb. The injection site is shown in $E$ (arrowhead). $C x$, Cortex; $G E$, ganglionic eminence; $O E$, olfactory epithelium. Scale bars: $A, 200 \mu \mathrm{m} ; B, C, 100 \mu \mathrm{m} ; D$, $F, 50 \mu \mathrm{m}$.

The final products cloned into a $\mathrm{T}$ vector prepared from pBluescript II $\mathrm{KS}$ and sequenced on an ABI377 through the University of Colorado Cancer Center DNA Sequencing Core. The $0.9-\mathrm{kb}$ product is identical to base pairs 143-1056 of the recently published mouse $H$-Sema IV homolog (Eckhardt and Meyerhans, 1998).

In situ hybridization. E14-E15 embryos (five to seven animals each) were perfused with $4 \%$ paraformaldehyde in $0.1 \mathrm{M}$ phosphate buffer, $\mathrm{pH}$ 7.4 (PFA). Brains were post-fixed in 4\% PFA, cryoprotected with $10 \%$ sucrose, and sectioned at $20 \mu \mathrm{m}$ with a cryostat. Antisense riboprobes were labeled with digoxigenin-dUTP (Boehringer Mannheim, Mannheim, Germany) or ${ }^{35} \mathrm{~S}$-UTP (Amersham, Buckinghamshire, UK) as described elsewhere (Chédotal et al., 1998). Controls including hybridization with sense riboprobes prevented hybridization signals.

Explant cultures and co-cultures. The olfactory bulbs from E14-E15 embryos were dissected out as a single piece, and 250-350 $\mu \mathrm{m}$ explants were obtained using fine tungsten needles (Pini, 1993). Only the rostral two-thirds of the bulb were used to try to eliminate most of the accessory olfactory bulb. Explants were co-cultured with aggregates $(\sim 750 \mu \mathrm{m}$ in diameter) of COS cells transfected with secreted alkaline phosphatase (AP), using the AP-Tag-4 vector (a gift from Dr. J. Flanagan, Harvard University, Boston, MA), or human sema III-myc (Messersmith et al., 1995), human sema IV-AP (Chen et al., 1997), mouse sema E-AP (Chen et al., 1997), mouse sema A-myc, or mouse sema H-myc (Chédotal et al., 1998). COS cell aggregates were prepared using the hanging drop method (Kennedy et al., 1994). Expression was controlled on Western blots using the monoclonal 9E10 anti-myc antibody or a polyclonal anti-AP antibody (Dako, High Wycombe, UK). Explants were embedded in rat tail collagen gel as previously described (Lumsden and Davies, 1986), and cultured for 36-60 hr in DMEM (Seromed, Berlin, Germany) supplemented with L-glutamine, D-glucose, and 10\% horse serum (all from Life Technologies, Gaithersburg, MD). Co-cultures were incubated in a $5 \% \mathrm{CO}_{2}, 37^{\circ} \mathrm{C}, 95 \%$ humidity incubator.

Explants were fixed for $1 \mathrm{hr}$ in ice-cold $4 \%$ PFA. For the visualization of neuronal processes, cultures were rinsed several times in $0.1 \mathrm{M}$ PBS, blocked with $1 \%$ normal goat serum, incubated with a neuron-specific anti-class III $\beta$-tubulin monoclonal antibody (1:3000, clone TUJ-1; 
1

23

4

5

6

204 -

121 -
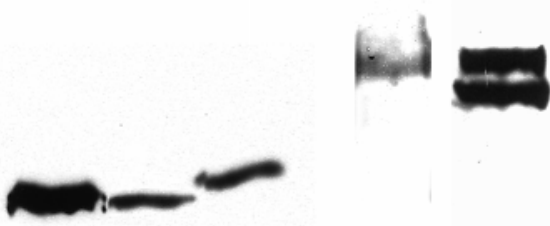

78 -

\section{$H$}

A III

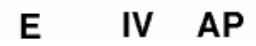

Figure 2. Western blot analysis of epitope-tagged secreted semaphorins. Recombinant proteins were collected in the supernatant of transfected COS cells and analyzed with anti-myc (lanes 1-3) or anti-AP (lanes 4-6) antibodies. The myc tag is at the $\mathrm{C}$ terminus, whereas the AP tag is at the $\mathrm{N}$ terminus. In lane 6 , a single band of $\sim 70 \mathrm{kDa}$ is detected and corresponds to COS cells expressing only secreted AP. For Sema H (lane 1), Sema A (lane 2), Sema III (lane 3), and Sema E-AP (lane 4 ) a single band is observed at their expected molecular weight. In the case of Sema IV-AP (lane 5) two bands are detected, the top one at the expected molecular weight of $160 \mathrm{kDa}$ and the bottom one at $\sim 130 \mathrm{kDa}$, probably corresponding to a partially cleaved protein.

Babco, Richmond, CA; Moody et al., 1989), followed by an HRPconjugated donkey anti-mouse antibody (1:2000; Jackson ImmunoResearch, West Grove, PA), and developed with a diaminobenzidine reaction. Other co-cultures were kept in $4 \%$ PFA, and the olfactory bulb explant was injected with a small crystal of lipophilic tracer 1,1'dioctadecyl-3,3,3',3' tetramethylindocarbocyannine (DiI; Molecular Probes, Eugene, OR). After $7-14 \mathrm{~d}$ at $37^{\circ} \mathrm{C}$ in the dark, to allow the diffusion of the tracer, explants were recorded and photographed under rhodamine fluorescent optics.

Quantification. After $\beta$-tubulin immunostaining or DiI labeling, the surface covered by the neurites growing from the explant was measured in the proximal and distal quadrants (Wang et al., 1996) using Imstar (Paris, France) software. Microphotographs of each individual explant were digitally scanned with a Nikon CP-9003 camera and transfer to a computer (Imstar). The contour of the area covered by the neuritic processes was acquired by hand with computer-aided filling using a specially devised package from Imstar (see Fig. 4C). This measure takes into account both neurite lengths and numbers. In addition, the average length of the neuritic bundles (three to four were used in each quadrant) was measured together with the distance separating the explants from the COS aggregates. Moreover, the mean number of neurites in both the proximal and distal quadrants was also determined (see Table 2). Finally, individual cultures were additionally classified as described in Table 1. Data were statistically analyzed using the Student's $t$ test or paired $t$ test and their corresponding nonparametric tests (Mann-Whitney and Wilcoxon tests, respectively).

\section{RESULTS}

\section{Early development of the rat lateral olfactory tract}

At E14-E15 the olfactory bulb can be clearly distinguished at the rostral end of the forebrain, allowing us to inject tiny DiI crystals in the bulb primordium (Fig. 1E). Such injections lead to the anterograde tracing of a compact axonal bundle that runs rostrocaudally just under the pial surface (Fig. 1) and corresponds to the presumptive LOT. Dorsoventrally, the LOT is at equal distance from the cortex and the septum (Fig. $1 A-C$ ). Laterally, the LOT is near a relatively thin leaflet of mesenchymal cells that represents the precursors of the frontal bone (Fig. 1B,D,F, arrowheads). They are so closed that the lipophilic dye can, in some cases, diffuse from the LOT to the mesenchyme (Fig. $1 C$ ). The schematic representation in Figure 7 summarizes the embryonic position of olfactory bulb projecting neurons (in red) and possible interactions with closely related cells.

\section{LOT axons are repelled by Sema IV and attracted by Sema A}

To test directly whether secreted semaphorins influence the growth of bulbofugal axons, we cultured olfactory bulb explants (from E14-E15 rat embryos) with COS cells that had been transiently transfected with expression constructs for all five known mammalian secreted semaphorins (A, III/D, E, IV, and H). Explants were cultured for 36-60 hr, fixed, and stained with an anti-class III $\beta$-tubulin monoclonal antibody that labels the entire population of axons growing from the explant (Moody et al., 1989). The expression of the diverse epitope-tagged semaphorins was verified by Western blotting (Fig. 2). Under nonreducing conditions, all secreted semaphorins, with the exception of Sema IV (see below), run as a single band (at the expected molecular weight of $\sim 95 \mathrm{kDa}$ for myc-tagged Sema A, Sema III, and Sema $\mathrm{H}$, and $\sim 160 \mathrm{kDa}$ for AP-tagged Sema E). In the case of Sema IV two bands were observed, one at $\sim 160 \mathrm{kDa}$ and another one at $\sim 130 \mathrm{kDa}$, which could represent a partially cleaved fragment. This suggests that in COS cells, most of the secreted semaphorins are not cleaved before secretion, contrary to what has been observed using 293 T cells (Adams et al., 1997). Observations similar to ours were made using an Fc-tagged collapsin-1 (Eickholt et al., 1997).

We found that olfactory bulb axons grow symmetrically when confronted with COS cells mock-transfected or transfected with an alkaline phosphatase expression construct (Figs. 3A, 4; Table 1 ). We could not detect any effect of COS cells secreting Sema III, Sema E, or Sema H (Fig. $3 B-D$, Table 1). In all these cases the surface covered by neurites was similar in the proximal and distal quadrants. In contrast, olfactory bulb axons were strongly repelled when confronted with COS cells expressing Sema IV (Figs. $3 E$, 4; Table 1). Repulsion could be clearly detected after $36 \mathrm{hr}$ in vitro but was stronger after $60 \mathrm{hr}$; therefore, quantification was done at that stage. The area covered by the neurites and the mean number of neurites in the distal quadrant were more than two times larger than in the proximal quadrant (Fig. 4B, Table 2). Neurites were also much longer in the distal $(372.4 \pm 15.7 \mu \mathrm{m}$; $n=83)$ than in the proximal $(234.8 \pm 9.8 \mu \mathrm{m} ; n=83)$ quadrant, suggesting that Sema IV somewhat reduces the growth of olfactory bulb (OB) axons. Moreover, a strong or moderate repulsion was observed in $54 \%$ of the cases (Fig. $4 A$, Table 1).

Neurite outgrowth was also asymmetrical in the case of explants facing Sema A-expressing COS cell aggregates. Surprisingly, Sema A appeared to exert a moderately attractive effect on olfactory bulb neurites (Figs. 3F, 4; Table 1). The neurite surface in the proximal quadrant was significantly higher of $33 \%$ when compared with the distal one (Fig. $4 B$ ), and the mean number of neurites in the proximal quadrant was very significantly increased (Table 2). In addition, chemoattraction was observed in $40 \%$ of the explants in comparison with $11 \%$ of control COS cells or $0 \%$ of Sema IV-expressing cells (Fig. 4B, Table 1). Repulsion with Sema A was observed in merely $9 \%$ of the explants (Fig. $4 A$, Table 1). This attractive effect is comparable with the one that has been recently shown for Sema E on neocortical axons (Bagnard et al., 1998). In addition, the average length of neurite bundles was comparable in the proximal $(273 \pm 8 \mu \mathrm{m} ; n=92)$ and distal $(231 \pm 10 \mu \mathrm{m} ; n=92)$ quadrants and similar to the average distance $(266 \pm 10 \mu \mathrm{m} ; n=92)$ between the explants and the COS aggregates. This shows that the Sema A has essentially 



D

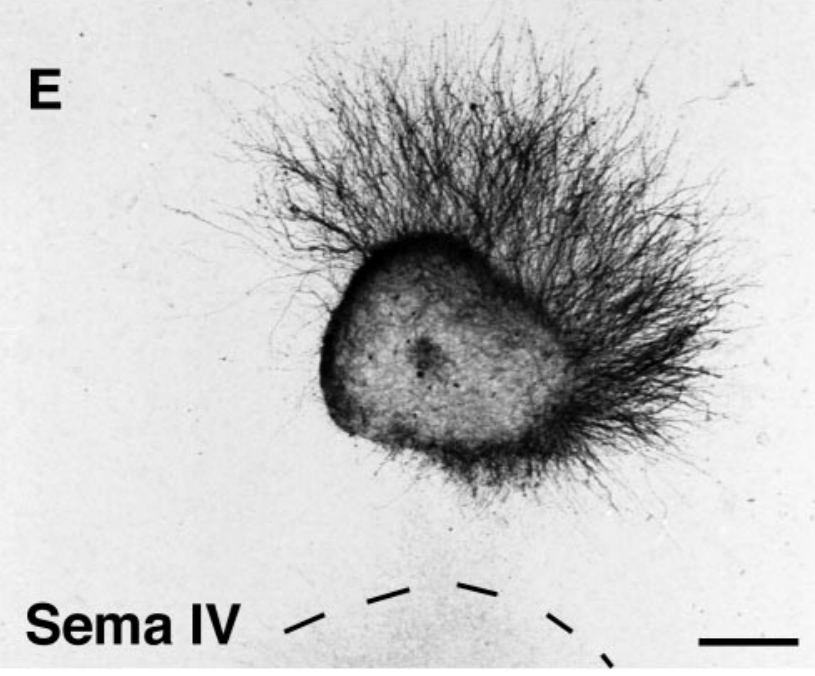

F

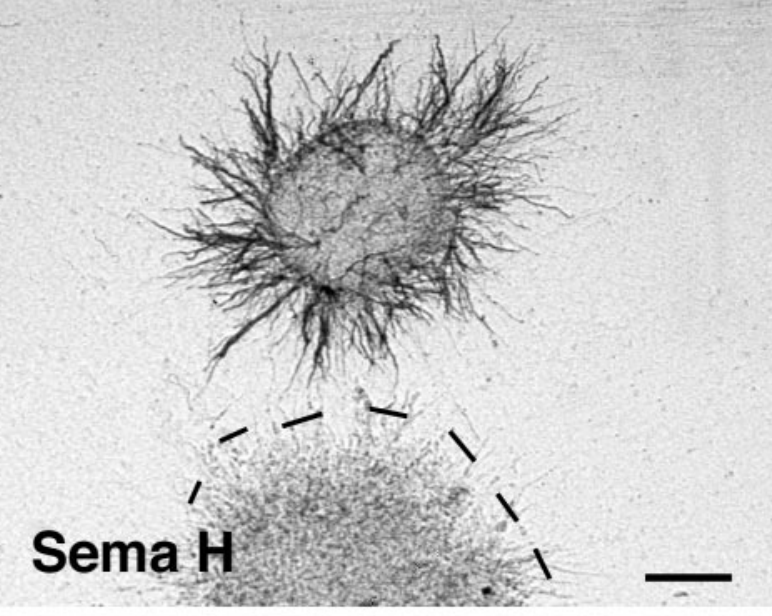

Sema H

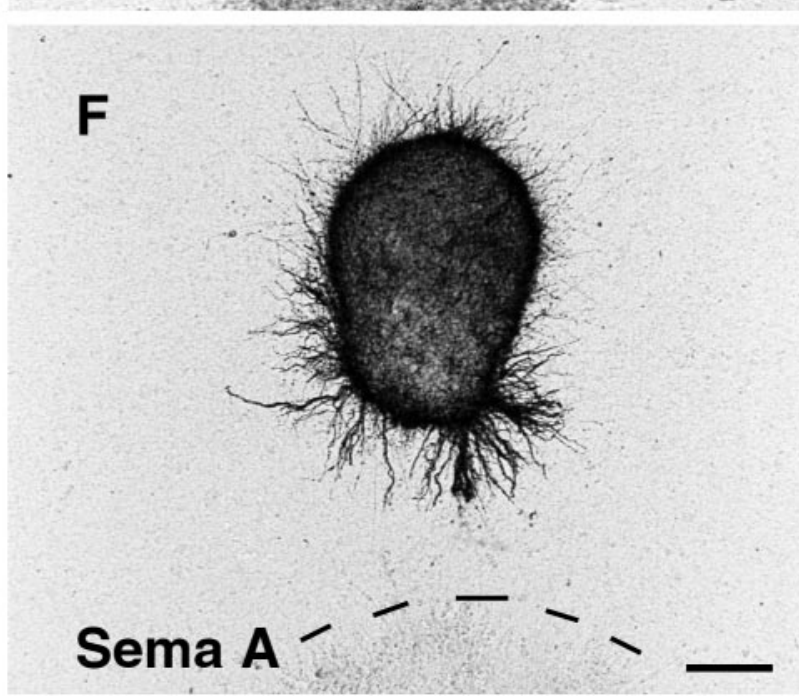

Figure 3. Illustration of the co-culture experiments. E14-E15 rat olfactory bulb explants were co-cultured 60 hr next to aggregates of control COS cells $(A)$ or COS cells transfected with $H$-sema III $(B)$, mouse sema $E(C)$, mouse sema $H(D), H$-sema $I V(E)$, or mouse sema $A(F)$. All explants were fixed and stained with anti- $\beta$-tubulin antibodies. Olfactory bulb axons grow symmetrically, in the case of control cells $(A)$ and COS cells expressing Sema III $(B)$, Sema $\mathrm{E}(C)$, and Sema $\mathrm{H}(D)$, whereas they are strongly repelled by Sema IV-expressing COS cell aggregates $(E)$. With Sema A-expressing cells $(F)$, olfactory bulb axons grow in all quadrants, but they are more numerous in the quadrant facing the COS cells aggregate, indicative of an attraction. Scale bars: $A-D, 170 \mu \mathrm{m} ; E, F, 150 \mu \mathrm{m}$. 
Table 1. Semiquantitative evaluation of the effect of secreted Semaphorins and olfactory epithelium (OE) on axonal outgrowth of olfactory bulb explants

\begin{tabular}{lrrrrrr} 
& \multicolumn{7}{c}{ Axonal outgrowth } & & & \\
\cline { 2 - 7 } Coculture condition & \multicolumn{1}{c}{$n$} & ++ & + & $=$ & - & -- \\
\hline COS control & 71 & 3 & 5 & 51 & 8 & 4 \\
Sema III & 34 & & 2 & 28 & 4 & \\
Sema E & 48 & & 5 & 36 & 7 & \\
Sema H & 24 & & 3 & 18 & 3 & \\
Sema A & 109 & 15 & 27 & 57 & 5 & 5 \\
Sema IV & 96 & & & 44 & 16 & 36 \\
OE & 56 & 1 & 9 & 17 & 11 & 18
\end{tabular}

Explants were labeled using anti- $\beta$-tubulin antibodies. Co-cultures were classified as follows: ++ , strong axonal attraction (surface occupied by axonal growth is more than threefold larger in the proximal than in the distal quadrant); +, moderate attraction of axons (axonal surface is twofold to threefold larger in the proximal than in the distal quadrant); =, radial axonal growth (axonal surface in the proximal and distal quadrants differed by less than twofold); -, moderate axonal repulsion (neurite surface twofold to threefold larger in the distal than in the proximal quadrant); --, strong axonal repulsion (surface occupied by axons is more than threefold broader in the distal than in the proximal quadrant).

a directional effect and does not stimulate the growth. Repulsive secreted semaphorins also have mostly a directional action (Messersmith et al., 1995; Song et al., 1998).

\section{Sema A and Sema IV expression in the rat olfactory system}

We tried to determine the possible function of Sema A and Sema IV in the development of the LOT in vivo by studying the expression pattern of their mRNAs in E14-E15 rat embryos (Fig. 5). At E15, sema $A$ mRNA was not detected in the forebrain (Fig. $5 A, B$ ), as previously mentioned (Püschel et al., 1996). Nevertheless, we could observe a strong expression of sema $A$ in the mesenchyme precursor of the frontal bone extending from the base of the olfactory bulb rostrally to the piriform cortex caudally (Fig. 5A,B). Therefore, sema $A$ expression is restricted to cells that are juxtaposed to the pathway followed by LOT axons. sema $I V$ was expressed in the cortical plate of the neocortex, as previously described (Chédotal et al., 1998), and in the ganglionic eminence (Fig. 5C,D). High sema IV mRNA expression was also observed in the olfactory epithelium (Fig. $5 E$ ) and was absent from the septum (Fig. 5C,D). In addition, at E15, sema IV mRNA was not expressed in the olfactory bulb (results not shown).

\section{Chemorepulsion of olfactory bulb axons by the olfactory epithelium}

Because Sema IV repels LOT axons and is highly expressed in the olfactory epithelium, we tried to determine whether we could show long-range effects of the olfactory epithelium on olfactory bulb axons. We therefore co-cultured in collagen gel E14-E15 olfactory bulb explants next to olfactory epithelial explants. In $52 \%$ of the cases, the growth of olfactory bulb axons, visualized with DiI, was opposed to the epithelial explant (Figs. 4A, 6; Table 1 ), and neurites were significantly more numerous in the distal quadrant than in the proximal one (Table 2). This demonstrates that the embryonic olfactory epithelium secretes a factor repulsive for olfactory bulb axons.

We also tried to co-culture olfactory bulb explants next to explants of mesenchyme surrounding the LOT but could not observe clear attractive or repulsive effects, because in $24 \mathrm{hr}$ mesenchymal cells migrate in the collagen gel and reach and partially cover OB explants (results not shown).
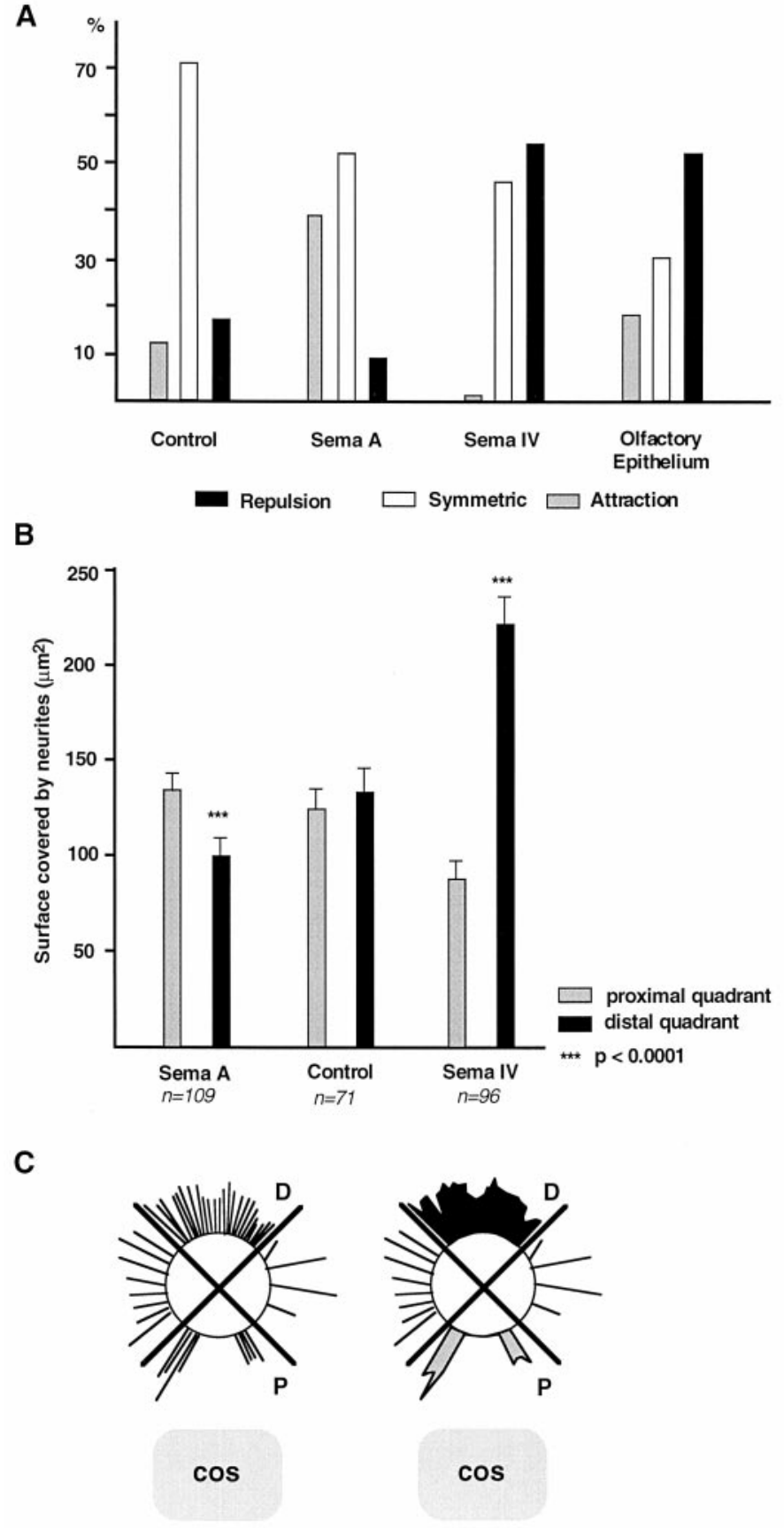

Figure 4. A, Histogram summarizing the data shown in Table 1 and illustrating the proportion (percent) of olfactory bulb explants in which axons look attracted, repelled, or unaffected when co-cultured next to control COS cells, Sema A- or Sema IV-expressing cells, and olfactory epithelium. $B$, Histogram showing the axonal surface (mean \pm SEM) in the different combinations of olfactory bulb explants and COS cells. All explants were fixed and stained with anti- $\beta$-tubulin antibodies. The axonal surface was measured in the distal (black bars) and proximal (gray bars) quadrants, as indicated in $C$. Olfactory bulb axons are strongly repelled by Sema IV but attracted by Sema A. Control COS cells have no effect. The asterisks denote differences between both quadrants (proximal and distal) that are significant at the $p=0.0001$ level (Mann-Whitney rank sum test and Wilcoxon signed rank test). $C$, Schema of the method used to quantify neurite outgrowth. An image analysis system was used to determine the overall area covered by neurites in the proximal $(P$, gray area $)$ and distal $(D$, black area $)$, as represented on the right. This gives an estimate of neurite lengths and numbers. 
Table 2. Mean number of neurite bundles in $\mathrm{OB}$ explants in different coculture conditions

\begin{tabular}{lllll} 
& & \multicolumn{2}{l}{ Mean no. of neurite bundles \pm SEM } & \\
\cline { 3 - 4 } Coculture conditions & $n$ & Proximal quadrant & Distal quadrant & $p$ \\
\hline OB + COS control & 10 & $46.3 \pm 10$ & $46.7 \pm 11$ & NS $(>0.05)$ \\
OB + Sema A & 10 & $65.2 \pm 18$ & $24.8 \pm 7$ & $<0.0001$ \\
OB + Sema IV & 10 & $24.9 \pm 7$ & $73 \pm 11$ & $<0.0001$ \\
OB + OE & 10 & $17.9 \pm 6$ & $57.8 \pm 13$ & $<0.0001$ \\
\hline
\end{tabular}

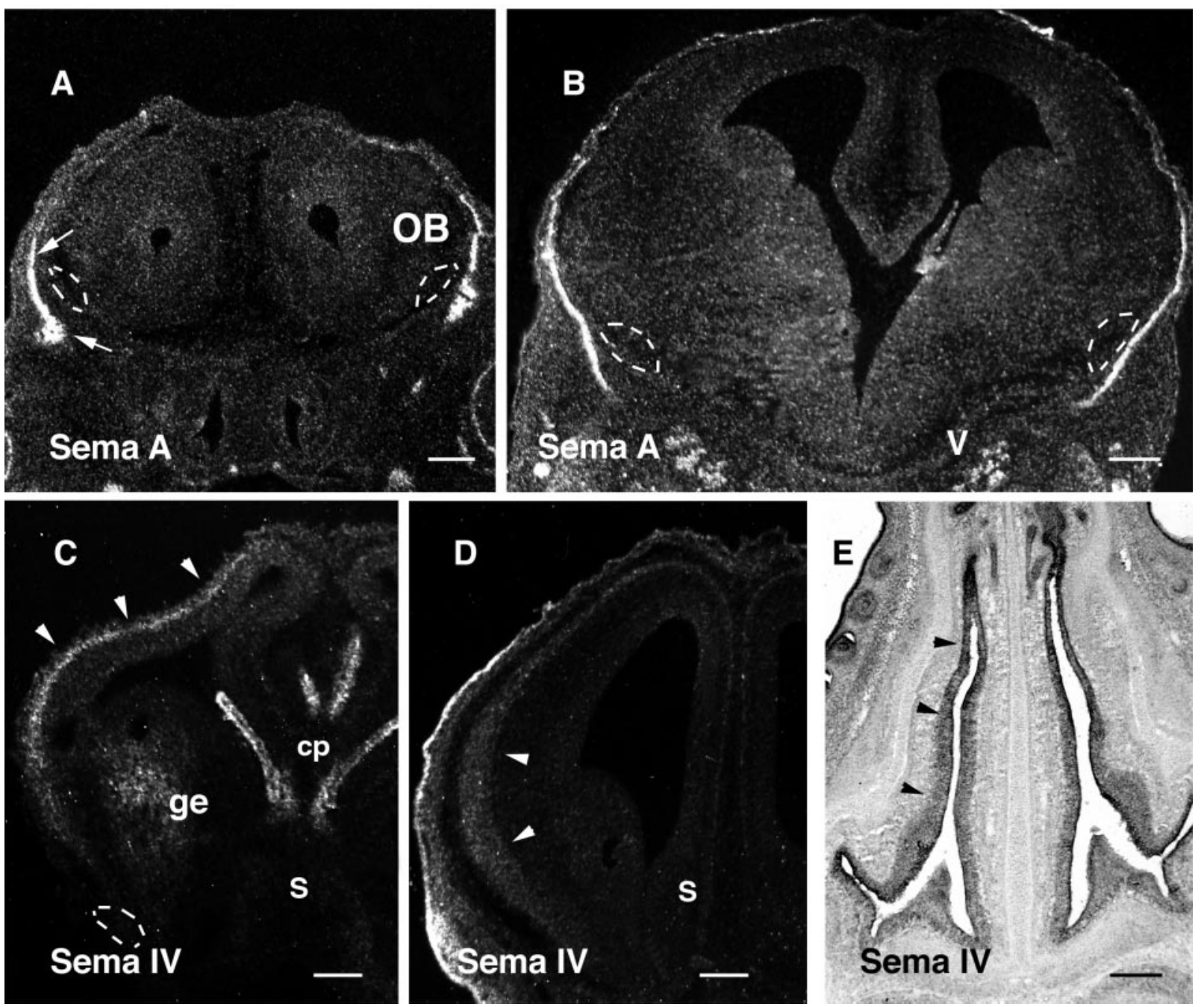

Figure 5. Expression pattern of sema $A$ and sema $I V$ in the developing head. Hybridizations were performed with ${ }^{35}$ S-labeled $(A-D)$ or digoxigeninlabeled $(E)$ riboprobes on coronal $(A-D)$ and horizontal $(E)$ sections of E15 rat brains. The prospective location of the LOT is delimited by dashes in $A-C$. $A, B$, sema $A$ mRNA is found in the mesenchyme precursor of the frontal bone $(A$, arrows), immediately adjacent to the LOT. Expression starts at the base of the $\mathrm{OB}$ in $A$ and runs caudally to the level of the trigeminal ganglion $(V)$ that is also expressing sema $A$ (see $B$ ). $C, D$, sema IV is expressed in the cortical plate (arrowheads) and in the ganglionic eminence ( $g e$ ). Strong expression is also found in the choroid plexuses $(c p)$ and the skin. Note in $C$ and $D$ that the septum $(S)$ is not expressing sema $I V$. In $E$, sema $I V$ expression is homogeneously high in the olfactory epithelium (arrowheads). Scale bars: $A, 215 \mu \mathrm{m} ; B, D, 110 \mu \mathrm{m} ; C, 240 \mu \mathrm{m} ; E$, and $300 \mu \mathrm{m}$.

\section{DISCUSSION}

We found that olfactory bulb axons, which will form the LOT, respond to Sema IV and Sema A but not to other secreted semaphorins. In collagen gel assays, Sema IV repels olfactory bulb axons, whereas, more surprisingly, Sema A acts as an attractant. In addition, in co-culture experiments, the olfactory epithelium exercises a repulsive action on the axons growing from olfactory bulb explants. Finally, the expression patterns of sema $A$ and sema $I V$ in the embryonic olfactory system and in structures next to the lateral olfactory tract strongly suggest that these semaphorins might play a role in the formation of the LOT.

Developing axons are known to be guided from a distance by diffusible molecules that can be attractive, repulsive, or both (Tessier-Lavigne and Goodman, 1996). Our results suggest that 


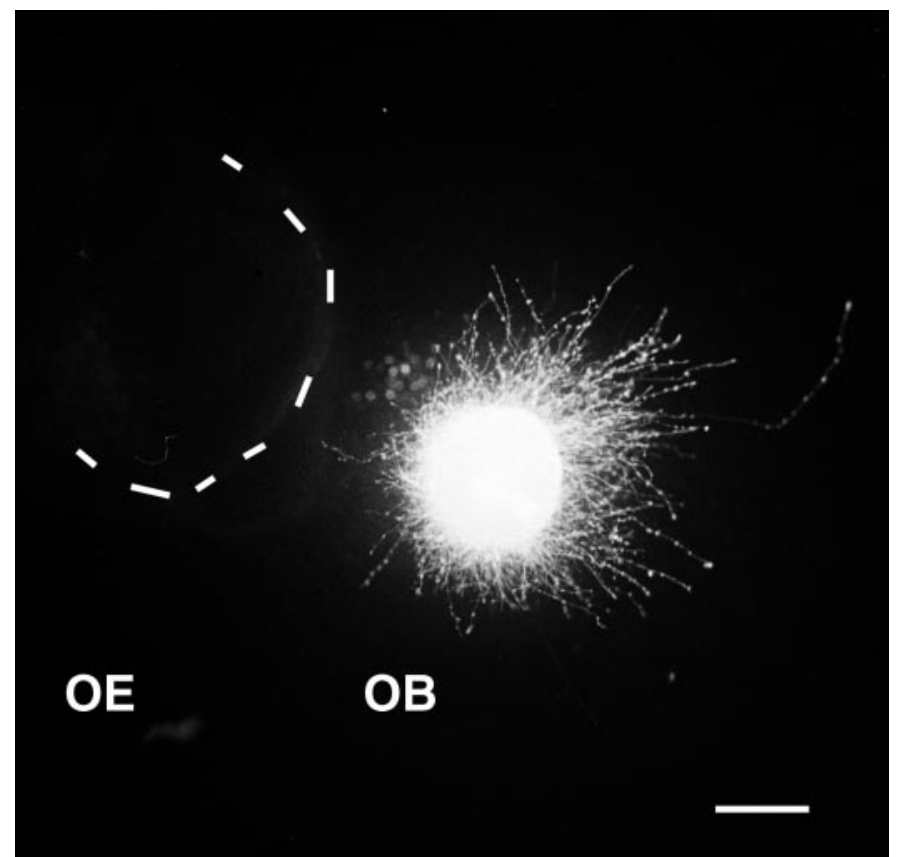

Figure 6. Olfactory bulb and olfactory epithelium cocultures. OB explants were labeled with DiI and placed near an unlabeled explant of olfactory epithelium (OE, dotted line). Labeled axons grow almost exclusively on the distal side of the explant opposite to the olfactory epithelium, indicating that the OE releases a diffusible repulsive factor. Scale bar, $200 \mu \mathrm{m}$.

chemoattraction and chemorepulsion exert a cooperative action during the development of the LOT. First, we showed that the olfactory epithelium releases a diffusible factor that repels olfactory bulb axons and could force them to leave the olfactory bulb primordium and grow caudally. This repellent effect is mimicked by Sema IV and not by any other secreted semaphorins or by netrin-1, another stong chemorepellent (F. de Castro, A. Chédotal, and C. Sotelo, unpublished observations). The finding that sema $I V$ is expressed in the olfactory epithelium (also see Giger et al., 1998) at the time LOT axons grow suggests that this molecule could be the epithelial-derived repellent factor (Fig. 7; see below). In addition, it is known that developing LOT axons never enter the embryonic neocortex (Schwob and Price, 1984), which produces a repulsive factor for LOT axons (Pini, 1993). sema $I V$, whose mRNA is highly expressed in the cortical plate of the neocortex (Chédotal et al., 1998; Giger et al., 1998 and present results), becomes an excellent candidate to be the secreted factor preventing the invasion of the neocortex by LOT axons (Fig. 7).

Chemorepulsion has been observed in several neuronal systems (Fitzgerald et al., 1993; Colomarino and Tessier-Lavigne, 1995; Tamada et al., 1995; Varela-Echavarría et al., 1997; Chédotal et al., 1998; Rochlin and Farbman, 1998; Tuttle et al., 1998), but the first evidence came from the embryonic rat olfactory system in which the septum produces a diff usible factor repelling olfactory bulb axons (Pini, 1993; Fig. 7). This still uncharacterized activity was supposed to explain why LOT axons grow away from the midline (Pini, 1993), although recent in vitro results have shown that mitral cell axons also elongate along their normal pathway without a septum (Sugisaki et al., 1995). Because Sema IV and the other known secreted semaphorins have not been found in the embryonic septum, the repulsive factor, produced by the latter, might not belong to the semaphorin family.
In addition, olfactory bulb axons grow preferentially toward aggregates of COS cells producing Sema A but not any other secreted semaphorins, suggesting that chemoattraction could also be involved in the formation of the LOT. In the embryonic rat head, sema $A$ mRNA is almost exclusively found in the frontal bone primordium that is apposed to the forebrain parenchyma and therefore immediately adjacent to the LOT, at a distance that could be smaller than $20 \mu \mathrm{m}$ (Meller and Tetzlaff, 1975). Although direct evidence is still lacking, our results suggest that Sema A released by the mesenchymal cells could attract in the CNS axons of the lateral olfactory tract. At this early stage, the immature meningeal covers are permeable, and the glia limitans is covered by a basal membrane, which prevents axons to leave the CNS. This could explain why LOT axons grow preferentially in the most superficial zone of the forebrain (Fig. 7). Sema A-mediated attraction was weaker than Sema IV repulsion, a difference that could emerge from the heterogeneity of olfactory bulb axons together with a differential action on a large axonal population for Sema IV and on a smaller one for Sema A (similarly, at E14 in the rat, Sema III repels only NGF-sensitive dorsal root ganglion axons but not NT3-sensitive ones; Messersmith et al., 1995). This assumption is based on the fact that mitral and tufted cells are morphologically, neurochemically, and functionally heterogeneous (Macrides et al., 1985; Shipley and Ennis, 1996).

It has recently been shown that Sema E can attract cortical axons (Bagnard et al., 1998). The present results confirm that in the vertebrate CNS, secreted semaphorins could promote the growth of certain axonal populations in normal developmental conditions. In addition, in cultured embryonic Xenopus spinal neurons, an experimental elevation of the cytosolic concentration of cGMP can turn Sema III repulsive action into an attraction (Song et al., 1998). Moreover, G-Sema I, a grasshopper transmembrane semaphorin that was previously shown to inhibit the growth of other sensory axons (Kolodkin et al., 1992), appears to promote the growth of axons in the subgenual organ (Wong et al., 1997). Similarly, Sema A, attractive in this study, is repellent for sympathetic axons (Adams et al., 1997; Takahashi et al., 1998). Therefore, we have enough evidence to start thinking that semaphorins might be bifunctional guiding cues, attractive and repulsive, like the midline-derived netrin-1 (Serafini et al., 1994; Colomarino and Tessier-Lavigne, 1995; Varela-Echavarría et al., 1997). Non-neuronal tissues, such as the somites, are known to influence the patterning of axonal projections in the peripheral nervous system (Tannahill et al., 1998). In addition, diffusible factors produced by the the notochord and other mesodermic tissues play a role in neuronal differentiation in the CNS (LaMantia et al., 1993; Rubenstein and Beachy, 1998). To our knowledge, the present results represent the first evidence for a presumptive influence of non-neuronal peripheral tissue on axon tract formation and orientation in the vertebrate CNS.

The identity of the receptors involved in Sema A and Sema IV signaling in olfactory bulb axons is still unknown. The transmembrane proteins neuropilin-1 and -2 have been shown to be receptors, or components of receptors, for vertebrate-secreted semaphorins (Chen et al., 1997; Feiner et al., 1997, He and TessierLavigne, 1997; Kolodkin et al., 1997, Giger et al., 1998; Takahashi et al., 1998). Recently, it has been shown that Sema IV-induced repulsion of sensory axons is mediated by neuropilin-2 (Giger et al., 1998). Moreover, Sema A collapsing activity also requires neuropilin-2, perhaps in combination with neuropilin-1 (Takahashi et al., 1998). Both neuropilins are expressed by mitral neurons and mitral cell axons at the time they leave the olfactory 


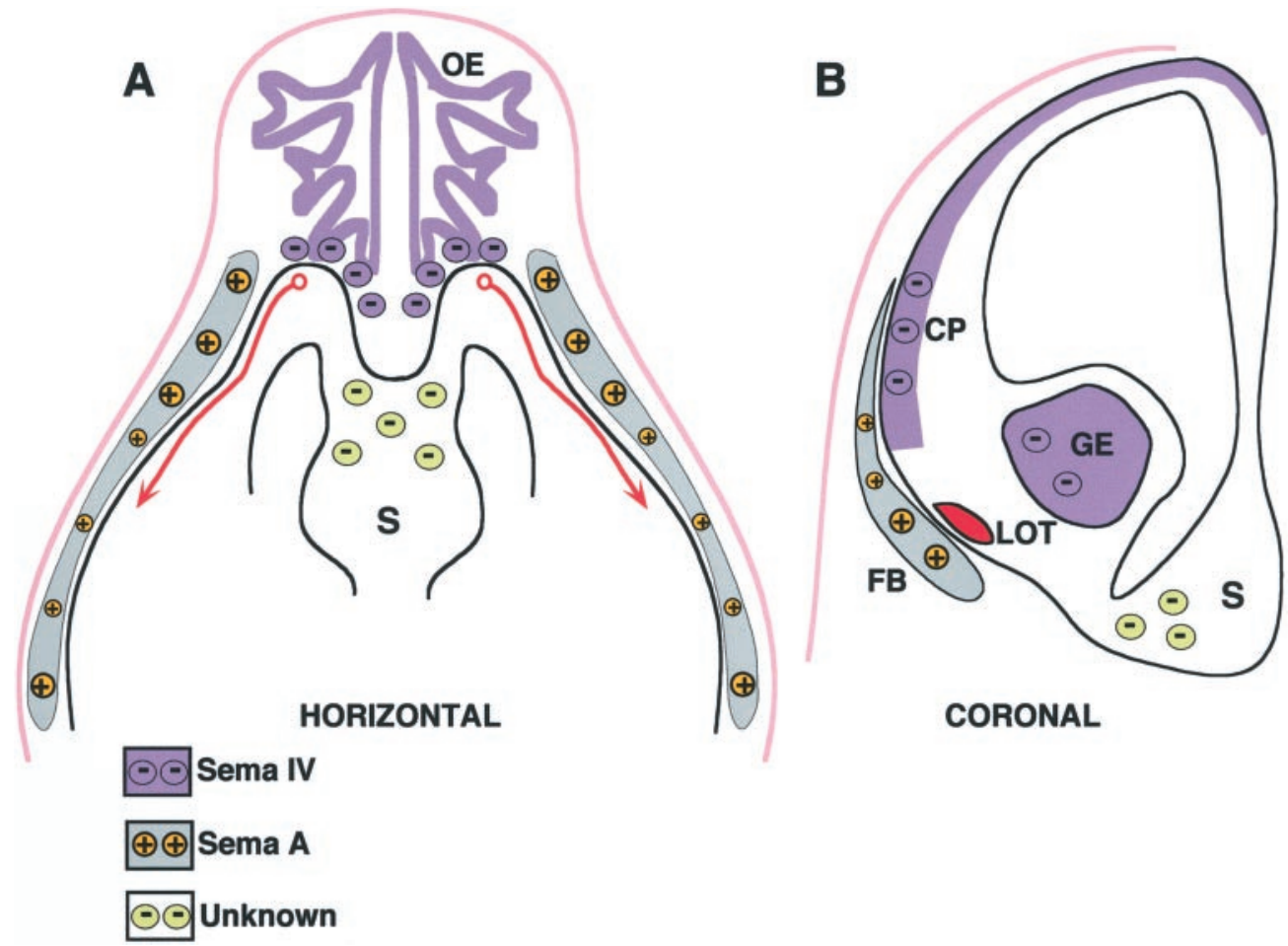

Figure 7. Schematic representation in horizontal $(A)$ and coronal $(B)$ planes of the chemorepulsive and chemoattractive factors that influence the formation of the lateral olfactory tract. The olfactory epithelium $(O E)$ would released a repulsive factor (violet circles), probably Sema IV, forcing LOT axons (red) to leave the olfactory bulb. An unidentified factor (green circles) produced by the septum $(S)$ would prevent LOT axons to cross the midline. In addition, LOT axons would grow very superficially, being attracted by Sema A (orange circles) secreted by the mesenchyme precursor of the frontal bone (gray). bulb (Sugisaki et al., 1995; Kawakami et al., 1996; Chen et al., 1997; F. de Castro and A. Chédotal, unpublished observations), but in neuropilin-1 knock-out mice (Kitsukawa et al., 1997) the LOT develops normally, suggesting that neuropilin-2 could be the receptor mediating Sema IV and Sema A responses. It would be interesting to determine whether the repulsive and attractive effects of Sema A are mediated by different receptors. In Xenopus axons, it is clear that the same second messengers may be used for both Sema III-mediated attraction and repulsion and that neuropilin-1 is the receptor for both (Song et al., 1998). Finally, the receptor might not be a neuropilin, because it has recently been shown that virus-encoded semaphorin protein receptor, a member of the plexin family of transmembrane proteins, is a receptor for a viral semaphorin (Comeau et al., 1998), and that in Drosophila, plexin A binds transmembrane semaphorins (Winberg et al., 1998). Whether plexins are receptors for other vertebrate-secreted or transmembrane semaphorins remains unknown (also see Fujisawa and Kitsukawa, 1998).

Semaphorins have been involved in the development and regeneration of other axonal connections of the olfactory system (Shepherd et al., 1996; Pasterkamp et al., 1998). Collapsin-1/Sema III can induce the collapse of olfactory axonal growth cones (Kobayashi et al., 1997) and could serve as a stop signal for these axons, initially preventing them from invading the olfactory bulb (Giger et al., 1996). Recently it has been shown that Sema A and Sema E can antagonize Sema III, preventing its binding to neuropilin-1 (Takahashi et al., 1998). Olfactory receptor neurons express Sema IV, which also binds neuropilin-1 but does not induce DRG growth cone collapse (A. Chédotal, unpublished observations) and could also be an antagonist of neuropilin-1. In agreement with Takahashi et al. (1998), Sema IV could act as a repellent for olfactory bulb axons and an antirepellent for olfactory axons, allowing them to enter the bulb even in the presence of a high concentration of Sema III in their target territory. Finally, several studies have shown that the formation of the olfactory bulb depends on the olfactory receptor neurons, independently of synapse formation (Graziadei et al., 1978; Stout and Graziadei, 1980; Gong and Shipley, 1995). The factors responsible for these actions have not been identified but it would be interesting to determine whether it could be a semaphorin.

In conclusion, during axonogenesis, LOT axons are probably influenced by multiple diffusible factors, repulsive and attractive, in combination with a variety of short-range cues (Sugisaki et al., 1995; Sato et al., 1998).

\section{REFERENCES}

Adams RH, Lohrum M, Klostermann A, Betz H, Püschel AW (1997) The chemorepulsive activity of secreted semaphorins is regulated by furin-dependent proteolytic processing. EMBO J 16:6077-6086.

Bagnard D, Lohrum M, Uziel D, Püschel AW, Bolz J (1998) Semaphorins act as attractive and repulsive guidance signals during the development of cortical projections. Development 125:5043-5053.

Bayer SA (1983) ${ }^{3} \mathrm{H}$-Thymidine-radiographic studies of neurogenesis in the rat olfactory bulb. Exp Brain Res 50:329-340.

Chédotal A, Del Río JA, Ruiz M, He Z, Borrell V, de Castro F, Ezan F, Goodman CS, Tessier-Lavigne M, Sotelo C, Soriano E (1998) Semaphorins III and IV repel hippocampal axons via two distinct receptors. Development 125:4313-4323.

Chen H, Chédotal A, He Z, Goodman CS, Tessier-Lavigne M (1997) Neuropilin-2, a novel member of the neuropilin family, is a high affinity receptor for the semaphorins sema E and sema IV but not sema III. Neuron 19:547-559.

Colomarino S, Tessier-Lavigne M (1995) The axonal chemoattractant netrin-1 is also a chemorepellent for trochlear motor axons. Cell 81:621-629.

Comeau MR, Johnson R, DuBose RF, Petersen M, Gearing P, VandenBos T, Park L, Farrah T, Buller RM, Cohen JI, Stockbine LD, Rauch C, Spriggs MK (1998) A poxvirus-encoded semaphorin induces cytokine production from monocytes and binds to a novel cellular semaphorin receptor, VESPR. Immunity 8:473-482.

Derer P, Caviness VS, Sidman RL (1977) Early cortical histogenesis in the primary olfactory cortex of the mouse. Brain Res 123:27-40.

Ebens A, Brose K, Leonardo ED, Hanson Jr MG, Bladt F, Birchmeier C, Barres BA, Tessier-Lavigne M (1996) Hepatocyte growth factor/scat- 
ter factor is an axonal chemoattractant and a neurotrophic factor for spinal motorneurons. Neuron 17:1157-1172.

Eckhardt F, Meyerhans A (1998) Cloning and expression pattern of a murine semaphorin homologous to H-sema IV. NeuroReport 9:3975-3979.

Eickholt BJ, Morrow R, Walsh FS, Doherty P (1997) Strutural features of collapsin required for biological activity and distribution of binding sites in the developing chick. Mol Cell Neurosci 9:358-371.

Feiner L, Koppel AM, Kobayashi H, Raper JA (1997) Secreted chick semaphorins bind recombinant neuropilin with similar affinities but bind different subsets of neurons in situ. Neuron 19:539-545.

Fitzgerald M, Kwiat GC, Middleton J, Pini A (1993) Ventral spinal cord inhibition of neurite outgrowth from embryonic rat dorsal root ganglia. Development 117:1377-1384.

Fujisawa H, Kitsukawa T (1998) Receptors for collapsin/semaphorins. Curr Opin Neurobiol 8:587-592.

Giger RJ, Wolfer DP, De Wit GMJ, Verhaagen J (1996) Anatomy of rat semaphorin III/collapsin-1 mRNA expression and relationship to developing nerve tracts during neuroembryogenesis. J Comp Neurol 375:378-392.

Giger RJ, Urquhart ER, Gillespie SKH, Levengood DV, Ginty DD, Kolodkin AL (1998) Neuropilin-2 is a receptor for semaphorin IV: insight into the structural basis of receptor function and specificity. Neuron 21:1079-1092.

Gong Q, Shipley MT (1995) Evidence that pioneer olfactory axons regulate telencephalon cell kinetics to induce the formation of the olfactory bulb. Neuron 14:91-101.

Graziadei PPC, Levine RR, Monti-Graziadei GA (1978) Regeneration of olfactory axons and synapse formation in the forebrain after bulbectomy in neonatal mice. Proc Natl Acad Sci USA 75:5230-5234.

He Z, Tessier-Lavigne M (1997) Neuropilin is a receptor for the axonal chemorepellent semaphorin III. Cell 90:739-751.

Hirata T, Fujisawa H (1997) Cortex-specific distribution of membranebound factors that promote neurite outgrowth of mitral cells in culture. J Neurobiol 32:415-425.

Hu H, Rutishauser U (1996) A septum-derived chemorepulsive factor for migrating olfactory interneuron precursors. Neuron 16:933-940.

Kawakami A, Kitsukawa T, Takagi S, Fujisawa H (1995) Developmentally regulated expression of a cell surface protein, neuropilin, in the mouse nervous system. J Neurobiol 29:1-17.

Kennedy TE, Serafini T, de la Torre JR, Tessier-Lavigne M (1994) Netrins are diffusible chemotropic factors for commisural axons in the embryonic spinal cord. Cell 78:425-435.

Kitsukawa T, Shimizu M, Sanbo M, Hirata T, Taniguchi M, Bekku Y, Yagi T, Fujisawa H (1997) Neuropilin-semaphorin III/D-mediated chemorepulsive signals play a crucial role in peripheral nerve projection in mice. Neuron 19:995-1005.

Kobayashi H, Koppel AM, Luo Y, Raper JA (1997) A role for collapsin-1 in olfactory and cranial sensory axon guidance. J Neurosci 17:8339-8352.

Kolodkin AL, Mathes DJ, O'Connor TP, Patel NH, Admon A, Bentley D, Goodman CS (1992) Fascilin IV: sequence, expression, and function during growth cone guidance in the grasshopper embryo. Neuron 9:831-845.

Kolodkin AL, Levengood DV, Rowe EG, Tai YT, Giger RJ, Ginty DD (1997) Neuropilin is a semaphorin III receptor. Cell 90:753-762.

LaMantia AS, Colbert MC, Linney E (1993) Retinoic acid induction and regional differentiation prefigure olfactory pathway formation in the mammalian forebrain. Neuron 10:1035-1048.

López-Mascaraque L, De Carlos JA, Valverde F (1996) Early onset of the rat olfactory bulb projections. Neuroscience 70:255-266.

Lumsden A, Davies AM (1986) Chemotropic effect of specific target epithelium in the development of the mammalian nervous system. Nature 323:538-539.

Macrides F, Schoenfeld TA, Marchand JE, Clancy AN (1985) Evidence for morphologically, neurochemically and functionally heterogeneous classes of mitral and tufted cells in the olfactory bulb. Chem Senses 10:175-202.

Marchand R, Bélanger MT (1991) Ontogenesis of the axonal circuitry associated with the olfactory system in the rat embryo. Neurosci Lett 129:285-290.

Mark MD, Lohrum M, Püschel A (1997) Patterning neuronal connections by chemorepulsion: the semaphorins. Cell Tissue Res 290:299-306.

Meller K, Tetzlaff W (1975) Neuronal migration during the early development of the cerebral cortex. Cell Tissue Res 163:313-325.
Messersmith EK, Leonardo ED, Shatz CJ, Tessier-Lavigne M, Goodman CS, Kolodkin AL (1995) Semaphorin III can function as a selective chemorepellent to pattern sensory projections in the spinal cord. Neuron 14:949-959.

Moody SA, Quigg MS, Frankfurter A (1989) Development of the peripheral trigeminal system in the chick revealed by an isotype-specific anti- $\beta$-tubulin monoclonal antibody. J Comp Neurol 346:97-118.

Pasterkamp RJ, De Winter F, Holtmaat AJGD, Verhaagen J (1998) Evidence for a role of the chemorepellent semaphorin III and its receptor neuropilin-1 in the regeneration of primary olfactory axons. J Neurosci 18:9962-9976.

Pini A (1993) Chemorepulsion of axons in the developing mammalian central nervous system. Science 261:95-98.

Püschel AW, Adams RH, Betz H (1996) The sensory innervation of the mouse spinal cord may be patterned by differential expression of and by differential responsiveness to semaphorins. Mol Cell Neurosci 7:419-431.

Roche J, Boldog F, Robinson M, Robinson L, Varella-Garcia M, Swanton M, Waggoner B, Fishel R, Franklin W, Gemmill R, Drabkin H (1996) Distinct 3p21.3 deletions in lung cancer, analysis of deleted genes and identification of a new human semaphorin. Oncogene 12:1289-1297.

Rochlin MW, Farbman AI (1998) Trigeminal ganglion axons are repelled by their presumptive targets. J Neurosci 18:6840-6852.

Rubenstein JLR, Beachy PA (1998) Patterning of the embryonic forebrain. Curr Opin Neurobiol 8:18-26.

Sato Y, Hirata T, Ogawa M, Fujisawa H (1998) Requirement for early generated neurons recognized by monoclonal antibody Lot1 in the formation of lateral olfactory tract. J Neurosci 18:7800-7810.

Schwob JE, Price JL (1984) The development of axonal connections in the central olfactory system of rats. J Comp Neurol 223:177-202.

Serafini T, Kennedy TE, Galko MJ, Mirzayan C, Jessell TM, TessierLavigne M (1994) The netrins define a family of axon outgrowthpromoting proteins homologous to C. elegans UNC-6. Cell 78:409-424.

Shepherd I, Luo Y, Raper JA, Chang S (1996) The distribution of collapsin mRNA in the developing chick nervous system. Dev Biol 173:185-199.

Shipley MT, Ennis M (1996) Functional organization of olfactory system. J Neurobiol 30:123-176.

Song H, Ming G, He Z, Lehmann M, McKerracher L, Tessier-Lavigne M, Poo M (1998) Conversion of neuronal growth cone responses from repulsion to attraction by cyclic nucleotides. Science 281:1515-1518.

Stout RP, Graziadei PPC (1980) Influence of the olfactory placode on the development of the brain in Xenopus laevis (Daudin)-I. Axonal growth and connections of the transplanted olfactory placode. Neuroscience 5:2175-2186.

Sugisaki N, Hirata T, Naruse Y, Kawakami A, Kitsukawa T, Fujisawa H (1995) Positional cues that are strictly localized in the telencephalon induce preferential growth of mitral cell axons. J Neurobiol 29:127-137.

Takahashi T, Nakamura F, Jin Z, Kalb RG, Strittmatter SM (1998) Semaphorins A and E act as antagonists of neuropilin-1 and agonists of neuropilin-2 receptors. Nat Neurosci 1:487-493.

Tamada A, Shirasaki, R, Murakami F (1995) Floor plate chemoattracts crossed axons and chemorepels uncrossed axons in the vertebrate brain. Neuron 14:1083-1093.

Tannahill D, Cook GMW, Keynes RJ (1998) Axon guidance and somites. Cell Tissue Res 290:275-283.

Tessier-Lavigne M, Goodman CS (1996) The molecular biology of axon guidance. Science 274:1123-1133.

Tuttle R, Braisted JE, Richards LJ, O'Leary DDM (1998) Retinal axon guidance by region-specific cues in diencephalon. Development 125:791-801.

Varela-Echavarría A, Tucker A, Püschel AW, Guthrie S (1997) Motor axon subpopulations are respond differentially to the chemorepellents netrin-1 and semaphorin D. Neuron 18:193-207.

Wang F, Nemes A, Mendelsohn M, Axel R (1998) Odorant receptors govern the formation of a precise topographic map. Cell 93:47-60.

Wang L-C, Rachel RA, Marcus RC, Mason CA (1996) Chemosupression of retinal axon growth by the mouse optic chiasm. Neuron $17: 849-862$.

Winberg ML, Noordermeer JN, Tamagnone L, Comoglio PM, Spriggs MK, Tessier-Lavigne M, Goodman CS (1998) Plexin A is a neuronal semaphorin receptor that controls axon guidance. Cell 95:903-916.

Wong JTW, Yu WTC, O'Connor TP (1997) Transmembrane grasshopper semaphorin I promotes axon outgrowth in vivo. Development 124:3597-3607. 